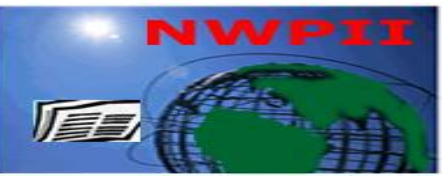

\title{
Association of Creatine Level and Hematological Parameters among Kidney Patients at Rwamagana Provincial Hoapital
}

\section{Aimé R. P. Ishimwe, Thierry Habyarimana, Joseph Mucumbitsi, Callixte Yadufashije and Francois N. Niyonzima*}

Department of Biomedical Laboratory Sciences, Faculty of Applied Fundamental Sciences, INES-Ruhengeri, Rwanda. "Corresponding Author

Dr Niyonzima N. Francois

Department of BLS, Faculty of AFS, INES-Ruhengeri, Musanze-155

Rwanda

Email: niyofra@yahoo.com; fniyonzima@ines.ac.rw

Mobile phone number: +250788536610

Received:10 November 2020; | Revised:21 December 2020; $\mid$ Accepted:09 March 2021

\begin{abstract}
Kidney disease is characterized by the presence of renal damage and/or decreased renal function. It is categorized as acute kidney injury or chronic kidney disease (CKD) based on disease duration and progressiveness. Staging of CKD is based on glomerular filtration rate and albuminuria. This study was carried out at Rwamagana provincial hospital in a span of 3 months from September to November 2019. The main objective was to assess the hematological parameters among patients with kidney diseases attending the hospital. Forty-eight participants were recruited based on inclusion criteria. Blood samples were collected to perform full blood count. Hematological parameters were measured using Sysmex XS 500i. Data analysis was carried out using statistical package for social science (SPSS). The results showed that males were highly affected $(70.8 \%)$ by kidney diseases in comparison to females $(29.2 \%)$. Anemia, thrombocytopenia and leukopenia were the commonest associated complication to kidney diseases. The overall association with creatinine levels and hematological parameters was statistically significant $\left(\mathrm{x}^{2}=49.67, \mathrm{P}<0.00001\right)$. The effect of creatinine to hematological parameters at the level of creatinine $(<53 \mu \mathrm{mol} / \mathrm{l})$ was statistically significant $\left(\mathrm{x}^{2}=42.18, \mathrm{P}=<0.00001\right)$. All hematological parameters were partially affected by creatinine levels. Thus, people at high risk for kidney diseases should be screened as it is asymptomatic in early stage.
\end{abstract}

Keywords: White blood cell, Hemoglobin, Kidney disease, Hematological parameters, Rwamagana provincial hospital 


\section{Introduction}

Kidney disease is an umbrella term for various disorders that affect the anatomy and function of the kidney ${ }^{[1]}$. It is regarded as worldwide health issue whose management should begin in its early stages [2]. It was found to be associated with haemopoietic changes ${ }^{[3]}$. It can also be detected with simple laboratory tests ${ }^{[4]}$. In Rwanda, CKD was reported to be ranged from 4 to $24 \%$ based predominantly on proteinuria as a marker ${ }^{[5]}$. As reported by Levey et al. ${ }^{[4]}$, the benefits of kidney disease treatment may include delaying its complications, minimizing the risks of cardiovascular diseases, and slowing down its progression. It has greater burden and very high cost of care, especially in developing countries like Rwanda.

Hematological parameters are commonly affected in kidney diseases. Of all the parameters, red cell indices are the ones commonly and severely affected. This is because with kidney disease, there is inadequate production of erythropoietin (EPO) ${ }^{[6]}$. Iron deficiency prevalence in CKD is around 49$55 \%$, and together with the comparative EPO deficiency, they represent the two main causes of anemia in $\mathrm{CKD}^{[7]}$. The alterations in red cell indices are attributed to numerous factors besides erythropoietin production.

Studies from Sub-Saharan Africa countries highlighted that the majority of kidney failure could presumably be ascribed to infections and hypertension. Malaria, Streptococcus, and tuberculosis are arguably among the important infectious causes ${ }^{[8]}$. Most patients with chronic kidney disease become anemic due to failure to erythropoietin secretion. Therefore, they should be periodically checked for anemia by measuring the serum hemoglobin level ${ }^{[9]}$. The assessment of the hematological changes in kidney disease patients attending Rwamagana provincial hospital in Rwanda is thus necessary. Habib et al. ${ }^{[10]}$ reported that hematological and biochemical parameters are mostly and frequently affected in CKD. This becomes more prominent as the disease advances which further complicates the condition of the patient.

Limited data are available on hematological parameters of patients with kidney diseases in Rwanda. Hematological and biochemical parameters in patients with chronic kidney disease were studied by Domina and Niyonzima ${ }^{[1]}$ at Kigali university teaching hospital. Available data has put much emphasize on anemia, but there are other affected hematological parameters including leucocytes and platelets counts. Therefore, it is of great importance to assess the hematological parameters among patients with CKD in other regions of Rwanda. In the present study, the hematological parameters among patients with kidney diseases attending Rwamagana provincial hospital were assessed.

\section{Materials and Methods}

\subsection{Study area and design}

This present study was carried out in medical laboratory of Rwamagana provincial hospital located in Rwamagana district, East province of Rwanda. The hospital accepts samples from different health centers and hospital including Gahengeri, Munini, Karenge, Rubona, Ruhunda, Avega, Muyumbu, Nzige, Nyakaliro, and Rwamagana health center and Kiziguro hospitals. It was a cross-sectional study that was conducted in 3 months, from September to November 2019. It involved patients already diagnosed with kidney diseases.

\subsection{Inclusion and exclusion criteria}

Participants included in this study were in and outpatients known to have kidney disease admitted in medical laboratory of the hospital. This study excluded pregnant and lactating women, patients who were suffering from any disease other than kidney disease that will affect their hematological parameters such as hematological malignancy, inherited or acquired blood disease, acute or chronic inflammation, dehydration or recent hemorrhagic episodes. The patients awaiting for renal transplantation were also excluded as a result of recent hemodialysis that could affect the results.

\subsection{Ethical consideration}

Protocol for this study was approved by both INES and hospital research committees prior to being done. The principal of confidentiality and respect of patient privacy were the rules as the research was carried out in health sector. Laboratory 
numbers were used as unique identifiers corresponding to the visit numbers of the hospital information system.

\subsection{Data collection and processing}

Data were collected using questionnaire that assisted in knowing the status information (sex, age, previous kidney disease history) and inclusion and exclusion criteria for the patients. Random sampling method was used to select study participants. For samples collection, the anatomical area of choice was cleaned with alcohol and allowed to air dry completely. Needle was inserted into the vein visible using the tourniquet. $4 \mathrm{ml}$ of blood was drawn into EDTA tube and shaken well. It was labeled with patients track net and then transported to the testing area of hematology service. The full blood count was performed using Sysmex XS 500i. It utilizes electrical impedance, flow cytometry and fluorescent flow cytometry techniques. RBCs, PLT and WBCs were identified from the performed full blood count. The descriptive statistic (chi square, measure of frequency) and tables were used for data presentation. Data were analyzed with SPSS version 22 software. The significance level was considered when $\mathrm{p}$ value was $<0.05$.

\section{Results}

\subsection{Social characteristics of the study population}

The hematological parameters among patients with kidney diseases attending Rwamagana provincial hospital were investigated. In the present study, compared to females, males were highly affected by kidney diseases. The patients in the age range of [41-60] years were more affected. They were followed by [20-40] years range (Table 1)

Table 1: Social characteristics of study population. $n=48$

\begin{tabular}{lll}
\hline & Sex & \\
\hline Age group & Male & Female \\
\hline$<20$ & $4(8.3 \%)$ & $1(2.1 \%)$ \\
\hline$[20-40]$ & $11(22.9 \%)$ & $6(12.5 \%)$ \\
\hline$[41-60]$ & $15(31.2 \%)$ & $5(10.5 \%)$ \\
\hline$>60$ & $4(8.3 \%)$ & $2(4.2 \%)$ \\
\hline Total & 34 & 14 \\
\hline
\end{tabular}

\subsection{Hematological parameters of the study participants}

Table 2 shows hematological parameters in kidney disease patients by gender. Indeed, red blood cells, platelets and white blood cells were highly reduced in males compared to females.

Table 2: Hematological parameters in kidney disease patients by gender. RBCs are red blood cells, PLT is platelet and WBCs are white blood cells

\begin{tabular}{lcccc}
\hline & \multicolumn{3}{c}{ Male } & \multicolumn{2}{c}{ Female } \\
\cline { 2 - 5 } & Below normal range & Above normal range & Below normal range & Above normal range \\
\cline { 2 - 5 } RBCs & 20 & 1 & 8 & 0 \\
\hline $\mathrm{Hb}$ & 20 & 1 & 8 & 0 \\
\hline PLT & 10 & 1 & 6 & 4 \\
\hline WBCs & 11 & 1 & 3 & 1 \\
\hline
\end{tabular}




\subsection{Association of creatinine and hematological parameters}

The association with creatinine and hematological parameters among the study participants with kidney diseases was determined. The overall association with creatinine and hematological parameters was statistically significant $\left(\mathrm{x}^{2}=49.67, \mathrm{P}<0.00001\right)$. There was statistical significance association $(\mathrm{x} 2=42.18, \mathrm{P}=<$ $0.00001)$ with creatinine level $(<53 \mu \mathrm{mol} / \mathrm{l})$ and all hematological parameters. Creatinine level at creatinine $>120 \quad \mu \mathrm{mol} / \mathrm{l}$ was not statistically significant $\left(\mathrm{x}^{2}=7.49, \quad \mathrm{P}=0.379701\right)$. All hematological parameters were partially affected by creatinine levels (Table 3 ).

Table 3: Association of creatinine and hematological parameters. RBCs is red blood cells, PLT is platelet and WBCs is white blood cells

\begin{tabular}{|c|c|c|c|c|c|c|c|c|c|c|c|}
\hline & \multicolumn{2}{|c|}{ Red blood cells } & \multicolumn{2}{|c|}{ Haemoglobin } & \multicolumn{2}{|c|}{ Platelets } & \multicolumn{2}{|c|}{ White Blood Cells } & \multirow[t]{2}{*}{$\begin{array}{l}\text { To } \\
\text { tal } \\
\end{array}$} & \multirow[t]{2}{*}{$x^{2}$} & \multirow[t]{2}{*}{$\mathbf{P}$} \\
\hline & $\begin{array}{l}<4.510^{6} \\
\text { cells } / \mu l\end{array}$ & $\begin{array}{l}\geq 610^{6} \\
\text { cells/ } \mu 1\end{array}$ & $\begin{array}{l}13.5 \\
\text { g/dl }\end{array}$ & $\begin{array}{l}17.5 \\
\text { g/dl }\end{array}$ & $\begin{array}{l}<150 \\
\text { cells/ } \mu \mathrm{l}\end{array}$ & $\begin{array}{l}\geq 450 \\
\text { cell } / \mu \mathrm{l}\end{array}$ & $\begin{array}{l}<4500 \\
\text { cells } / \mu l\end{array}$ & $\begin{array}{l}>11000 \\
\text { cells } / \mu l\end{array}$ & & & \\
\hline $\begin{array}{l}\text { Creatinine }<53 \\
\mu \mathrm{mol} / \mathrm{l}\end{array}$ & $0(3.53)$ & $1(0.25)$ & $\begin{array}{l}0(3.53 \\
) \\
\end{array}$ & $\begin{array}{l}1(0.2 \\
5) \\
\end{array}$ & $1(2.14)$ & $\begin{array}{l}5(0.75 \\
) \\
\end{array}$ & $1(1.8)$ & $4(0.63)$ & 13 & $\begin{array}{l}42 . \\
18\end{array}$ & $\begin{array}{l}<0.0 \\
0001 \\
\end{array}$ \\
\hline $\begin{array}{l}\text { Creatinine }>120 \\
\mu \mathrm{mol} / \mathrm{l}\end{array}$ & $28(24)$ & $1(1.7)$ & $28(24)$ & $\begin{array}{l}1((1 . \\
7)\end{array}$ & $\begin{array}{l}16((14 . \\
8)\end{array}$ & $1(5)$ & $14(13)$ & $1(4)$ & 90 & $\begin{array}{l}7.4 \\
9 \\
\end{array}$ & $\begin{array}{l}0.37 \\
9701 \\
\end{array}$ \\
\hline Total & 28 & 2 & 28 & 2 & 17 & 6 & 15 & 5 & $\begin{array}{l}10 \\
3 \\
\end{array}$ & $\begin{array}{l}49 . \\
67\end{array}$ & $\begin{array}{l}<0.0 \\
0001 \\
\end{array}$ \\
\hline Chi Square $\left(x^{2}\right)$ & 16.06 & & 16.06 & & $\begin{array}{l}13.796 \\
9\end{array}$ & & 10.7556 & & & & \\
\hline$P$ value $(P)$ & $<0.00001$ & & $<0.000$ & & 0.0002 & & 0.00104 & & & & \\
\hline
\end{tabular}

\section{Discussion}

The slow progression and loss of kidney function are both characteristics of kidney diseases that occur over time. Kidney diseases are associated with different risk factors that contribute to its increase in addition to natural aging of kidney ${ }^{[12]}$. Males were highly affected by kidney diseases compared to females. Similarly, males were high $(75 \%)$ than females $(25 \%)$ in a study carried out by Habib et al. ${ }^{[10]}$ at HAHC hospital in New Delhi (India). The majority of patients that were affected was in the [41-60] age range. Habib et al. ${ }^{[10]}$ also reported the maximum number of patients were in the age group of 41-60, followed by $21-40$ age group. The results of the current study are consistent with a study conducted by Asif et al. [13] that revealed that the difference in affected age group might be due to kidney function which tend to be lost by $1 \%$ every year after the age of 40 as people grow older, and also because kidney diseases can develop at any age. Anemia that parallels the degree of kidney dysfunction can be developed as soon as kidney function is starting to be lost. Gender difference might be due to metabolic adaptation, high alcohol intake, and smoking of males compared to females. Indeed, the mostly affected group were both young and old, who are at the productive age in the society. 
The greatest importance of hematological parameters is demonstrated by their ability to provide information on the balance between production and destruction of blood cells in the circulatory system ${ }^{[14]}$. Hematological parameters were highly reduced in males than females (Table 2). Similarly, anemia and thrombocytopenia were statistically high in acute kidney injury and CKD patients in a study conducted by Dorgalaleh et al. [15]. Inadequate production of EPO by the kidneys is found to be the main cause of anemia in patients with CKD ${ }^{[10]}$. Due to the fact that participants might have some degree of $\mathrm{CKD}$, hematological parameters are affected corresponding to the severity of CKD. This study also agrees to the one done by Iseki ${ }^{[16]}$ that showed that white blood cells (WBCs) and platelet (PLT) tend to decrease as people grow old and on the basis of gender. Indeed, old people tend to develop drinking habit instead of eating a healthier food. For this reason, bone marrow hematopoiesis is suppressed, as a result of reduced hematopoietic growth factors. It can also be due to some other chronic infections that are present in old ages hinder bone marrow blood cell production, hence promoting extramedular hematopoiesis $(\mathrm{EMH})$ that produce immature blood cells ${ }^{[13]}$.

The RBCs count, $\mathrm{Hb}$ concentration, and PLT count are decreased in kidney disease patients. There is a association between serum creatinine level and all hematological parameters, and the severity of the kidney disease determines the extent of changes [14]. A significant association was observed between creatinine and hematological parameters in study participants with kidney diseases. According to the study conducted at Kigali university teaching hospital by Domina and Niyonzima ${ }^{[11]}$, anemia was identified as a CKD complication that becomes more severe in proportion to kidney dysfunction. This matches with this study where anemia was present in the study population. Brugnara and Eckardt ${ }^{[14]}$ revealed that microcytic anemia $(\mathrm{MCV}<80 \mathrm{fl})$ is associated with CKD as a result of poor EPO secretion, blood loss and low serum iron. Iseki ${ }^{[16]}$ revealed that anemia correction by blood transfusion didn't reveal any improvement in CKD patients.

Kidney plays an important role in EMH from which platelets regulating hormone thrombopoietin is partially produced ${ }^{[17]}$. According to Jalal et al. ${ }^{[18]}$, platelets reduction is associated with CKD as it becomes more severe. It is in agreement with the study conducted in HAHC hospital in India (New Delhi) by Habib et al. ${ }^{[10]}$. They mentioned that platelets tend to be decreased in both predialysed and hemodialyzed patients even though thrombocytopenia is regarded as a consequence of hemodialysis. This study is in correspondence with other studies, where platelets were decreased in the study population ${ }^{[19]}$. Anemia in kidney disease participants might be caused mostly by iron deficiency as a result of appetite loss. Therefore, study participants might have other chronic disease that can cause anemia.

\section{Conclusion}

The aim of the research was to assess the hematological parameters among patients with kidney diseases attending Rwamagana provincial hospital. Kidney diseases present changes in various hematological parameters of which anemia was more common. The RBCs, Hb, PLT and WBCs revealed association with serum creatinine. As kidney diseases develop at any age, kidney disease patients should be screened for different predisposing factors that endanger their life including mostly diabetes, CVD and hypertension. There is a need for kidney disease patients to change their lifestyle by reducing alcohol intake, quit smoking, and improve physical activity.

\section{Conflict of Interest}

The authors report no form of conflict of interest in this work. No form of funding was received from any funding organization /agency for this work.

\section{Authors Contributions}

Conception or design: Aimé R. P. Ishimwe, Francois N. Niyonzima

Data acquisition and analysis: Aimé R. P. Ishimwe, Callixte Yadufashije

Manuscript writing and editing: Aimé R. P. Ishimwe, Thierry Habyarimana 
Manuscript revision: Thierry Habyarimana, Callixte Yadufashije

Final approval of the manuscript: Francois N. Niyonzima

\section{ORCID}

Callixte Yadufashije: https://orcid.org/00000002-3463-3725

Thierry Habyarimana: https://orcid.org/0000$\underline{0001-5488-5578}$

Francois N. Niyonzima: https://orcid.org/00000002-8228-5171

Joseph Mucumbitsi: https://orcid.org/0000$\underline{0002-9455-4981}$

\section{Acknowledgments}

The authors thank INES-Ruhengeri and Rwamagana provincial hospital for time and help

\section{References}

1 Levey, A. S.;Coresh, J.Chronic kidney disease, The Lancet, 2012, 379(9811), 165-180 DOI: $10.1016 / \mathrm{S} 0140-6736(11) 60178-5$

2 Inker LA, Astor BC, Fox CH, Isakova T, Lash JP, Peralta CA, Kurella Tamura M, Feldman HI. KDOQI US commentary on the 2012 KDIGO clinical practice guideline for the evaluation and management of CKD. $\boldsymbol{A m} \boldsymbol{J}$ Kidney Dis 2014; 63(5): 713-735 [PMID: 24647050 DOI: 10.1053/j.ajkd.2014.01.416]

3 Suresh, M.;Mallikarjuna, N. M, S. B. S.; Bandi, H. K.; Shravya, G. Hematological changes in chronic renal failure, International Journal of Scientific and Research Publications, 2012, 2(9),1-4.

4 Levey AS, Atkins R, Coresh J, Cohen EP, Collins AJ, Eckardt KU, Nahas ME, Jaber BL, Jadoul M, Levin A, Powe NR, Rossert J, Wheeler DC, Lameire N, Eknoyan G. Chronic kidney disease as a global public health problem: approaches and initiatives - a position statement from Kidney Disease Improving Global Outcomes. Kidney Int 2007; 72(3): 247-259 DOI: $10.1038 /$ sj.ki.5002343

5 Ngendahayo, F.; Mukamana, D.; Ndateba, I.; Nkurunziza, A.; Adejumo, O. Chronic kidney disease (CKD): knowledge of risk factors and preventive practices of CKD among students at a university in Rwanda, Rwanda Journal of Medicine and Health Sciences, 2019, 2(2),185-193 DOI: $10.4314 /$ rjmhs.v2i2.15

6 Jelkmann W. Molecular biology of erythropoietin. Intern Med 2004; 43(8): 649659 DOI: 10.2169/internalmedicine.43.649

7 Suega K, Kandarini Y, Tubung J. Role of Soluble Transferrin Receptor and Transferrin Receptor-Ferritin Index to Detect Iron Deficiency Anemia in Regular Hemodialysis Patients. Open Access Maced J Med Sci 2019; 7(1): 97-102 DOI: 10.3889/oamjms.2019.012

8 Arogundade FA, Barsoum RS. CKD prevention in Sub-Saharan Africa: a call for governmental, nongovernmental, and community support. Am J Kidney Dis 2008; 51(3): 515-523 DOI: 10.1053/j.ajkd.2007.12.006

9 Nurko S. Anemia in chronic kidney disease: causes, diagnosis, treatment. Cleve Clin J Med 2006; 73(3): 289-297 [PMID: 16548452 DOI: 10.3949/ccjm.73.3.289]

10 Habib,A.;Ahmad, R.;Rehman, S.Hematological changes in patients of chronic renal failure and the effect of hemodialysis on these parameters, International Journal of Research and Medical Science, 2017, 5(2), 4998-5003 DOI: 10.18203/2320-6012.ijrms20174959

11 Domina, N.; Niyonzima, F. N. Assessment of hematological and biochemical parameters in patients with chronic kidney disease attending Kigali university teaching hospital. INES Scientific Journal, 2018, 13,77-83

12 Murphy D, McCulloch CE, Lin F, Banerjee T, Bragg-Gresham JL, Eberhardt MS, Morgenstern H, Pavkov ME, Saran R, Powe NR, Hsu CY, Centers for Disease C, Prevention Chronic Kidney Disease Surveillance T. Trends in Prevalence of Chronic Kidney Disease in the United States. Ann Intern Med 2016; 165(7): 473-481 DOI: $\underline{\text { 10.7326/M16-0273 }}$

13 Asif, N.; Hasan, S.; Hassan, K. (2015). Hematological changes in patients of chronic renal disease and their response to treatment with erythropoietin, International Journal of Pathology, 2015, 13(1),14-19. 
14 Brugnara, C.; Eckardt, K. U. (2011). Brenner and Rector's the Kidney (9 ed.); Saunders: Philadelphia, 2015; pp 2081-2120

15 Dorgalaleh, A.; Mahmudi, M.; Tabibian, S.; Khatib, Z. K.; Tamaddon, G. H.; Moghaddam, E. S.; Moradi, E. (2013). Anemia and thrombocytopenia in acute and chronic renal failure, International Journal of HematologyOncology and Stem Cell Research, 2013, 7(4),34

16 Iseki K. Gender differences in chronic kidney disease. Kidney Int 2008; 74(4): 415-417 [PMID: 18670407 DOI: 10.1038/ki.2008.261]

17 Ricci D, Mandreoli M, Valentino M, Sabattini E, Santoro A. Extramedullary haematopoiesis in the kidney. Clin Kidney J 2012; 5(2): 143145 DOI: $\underline{10.1093 / \mathrm{ckj} / \mathrm{sfs} 015}$
18 Jalal, D. I.;Chonchol, M.; Targher, G. Disorders of hemostasis associated with chronic kidney disease. In Jalal, D. I. (Ed.), Thrombosis and Hemostasis; Thieme Medical Publishers: Leipzig, 2010; pp 34-40.

19 Stevens PE, Levin A, Kidney Disease: Improving Global Outcomes Chronic Kidney Disease Guideline Development Work Group M. Evaluation and management of chronic kidney disease: synopsis of the kidney disease: improving global outcomes 2012 clinical practice guideline. Ann Intern Med 2013; 158(11): 825-830 DOI: 10.7326/0003-4819158-11-201306040-00007 